\title{
MENINGKATKAN KEMAMPUAN MENYIMAK MELALUI METODE BERCERITA PADA ANAK KELOMPOK A DI TK SITI KHODIJAH PUCUK LAMONGAN
}

\author{
Suhartini Nurul Azminah \\ STKIP Bina Insan Mandiri Surabaya Jl. Menganti Kramat No. 133 Wiyung Surabaya \\ Email: nurul.azmin55@gmail.com
}

Received February 2018, Accepted March 2018, Published April 2018

\begin{abstract}
Increasing Ability To Listen Through Story Methods in Children of Group A in Siti Khodijah Kindergarten Pucuk Lamongan. Listening has a fundamental function of life including the preschoolers. Human use more time of listening activities for about $50 \%$, while the rest $50 \%$ are used for speaking, reading, and writing. Listening activities should begin early for children in all situations. But, it is not in line with the listening ability of group A children in Kindergarten Siti Khodijah Pucuk Lamongan. They have some difficulties when being asked by the teacher to listen to information given. Listening is a tedious activity for children, especially preschoolers. It is necessary to have similar material and interesting way to practice listening skills in preschoolers. According to the problem, the research questions are formulated as follows (1) How the application of storytelling method to improve the listening ability of children group A in Kindergarten Siti Khodijah Pucuk Lamongan?, (2) How to improve the listening ability through the storytelling method of group A children in Kindergarten Siti Khodijah Pucuk Lamongan? The purpose of this study are (1) To find out how the application of storytelling method to improve the listening ability in children group A in Kindergarten Siti Khodijah Pucuk Lamongan, (2) To know the improvement of listening ability through storytelling method of group A in Kindergarten Siti Khodijah Pucuk Lamongan. This study uses a Classroom Action Research in which there are actions of teachers in two cycles. On the first cycle the percentage of children who are able based on criteria of Exponential Developing Criteria (BSH) reaches 33.33\% while in the second cycle the percentage of children who are able increases to $83.33 \%$. Based on the result of this study, it can be concluded that the method of storytelling can improve the listening ability of children group A in Kindergarten Siti Khodijah Pucuk Lamongan.
\end{abstract}

Keywords: listening ability, storytelling method.

Abstrak: Meningkatkan Kemampuan Menyimak Melalui Metode Bercerita pada Anak Kelompok A di TK Siti Khodijah Pucuk Lamongan. Menyimak memiliki fungsi pokok dalam kehidupan manusia termasuk dalam kehidupan anak prasekolah. Manusia menggunakan lebih banyak waktunya untuk kegiatan menyimak yakni sekitar 50\%, sedangkan 50\% yang lain digunakan untuk berbicara, membaca, dan menulis. Kegiatan menyimak harus mulai dibiasakan untuk anak sejak dini disegala situasi. Akan tetapi hal ini tidak sejalan dengan kemampuan menyimak anak-anak kelompok A di TK Siti Khodijah Pucuk Lamongan. Anak-anak kelompok A di TK Siti Khodijah Pucuk Lamongan banyak mengalami kesulitan ketika diminta guru untuk menyimak informasi yang diberikan oleh guru. Kegiatan menyimak adalah kegiatan yang membosankan bagi anak, khususnya anak prasekolah. Sehinga perlu bahan simakan dan cara emberian simakan yang menarik untuk melatih kemampuan menyimak pada anak prasekolah. Merujuk pada permasalahan tersebut maka dapat dirumuskan permasalahan (1) Bagaimana penerapan metode bercerita untuk meningkatkan kemampuan menyimak pada anak kelompok A di TK Siti Khodijah Pucuk Lamongan?, (2). Bagaimana peningkatan kemampuan menyimak melalui metode bercerita pada anak kelompok A di TK Siti Khodijah Pucuk Lamongan?. Tujuan dari penelitian ini adalah (1). Untuk mengetahui bagaimana penerapan metode bercerita untuk meningkatkan kemampuan menyimak pada anak kelompok A di TK Siti Khodijah Pucuk Lamongan, (2). Untuk mengetahui peningkatan kemampuan menyimak melalui metode bercerita pada anak kelompok A di TK Siti Khodijah Pucuk Lamongan. Penelitian ini menggunakan jenis Penelitian Tindakan Kelas yang di dalamnya terdapat tindakan dari guru dalam dua siklus. Pada sikus 1 persentase anak yang dapat dikatakan mampu dengan kriteria Berkembang Sesuai Harapan (BSH) mencapai 33,33\% Sedangkan pada siklus 2 persentase anak yang dikatakan mampu mengalami kenaikan menjadi $83,33 \%$. Dari hasil penelitian ini dapat disimpulkan bahwa metode bercerita dapat meningkatkan kemampuan menyimak pada anak kelompok A di TK Siti Khodijah Pucuk Lamongan.

Kata Kunci : Kemampuan Menyimak, Metode Bercerita. 
Bahasa merupakan bentuk komunikasi baik berupa lisan, tertulis atau tanda- tanda yang didasarkan pada sistem simbol (Santrock, 2010). Bahasa sebagai salah satu dari kemampuan dasar yang harus dimiliki anak memiliki beberpa tahapan sesuai dengan usia dan karakteristik perkembangannya (Dhieni, dkk, 2007). Pada usia Taman Kanak- Kanak, anak berada pada masa ekspresif, fase ini diawali dengan kemampuan anak dalam mendengar dan merekam bahasa serta percakapan yang didengar (Papalia dan Olds dalam Jamaris, 2005: 182).

Bahasa memiliki empat keterampilan yang merupakan caturtunggal, yaitu menyimak, berbicara, membaca, dan menulis. (Tarigan, 1994: 2). Menyimak bermakna mendengarkan dengan baik- baik apa yang diucapkan atau dibaca orang (KBBI, 2005: 1066). Lebih lanjut Wibowo (2007) menjelaskan bahwa menyimak merupakan kegiatan aktif yang dilakukan oleh seseorang untuk menangkap suatu informasi kemudian informasi tersebut diproses dan diolah. Hal ini berarti bahwa menyimak bukan hanya seseorang mendengar sesuatu kemudian diam dan tidak melakukan apapun, akan tetapi apa yang didengar tersebut langsung diproses secara aktif dan dihubungkan dengan pengetahuan awal yang dimiliki.

Menurut Dhieni, dkk (2007: 4.6) menyimak memiliki beberapa fungsi, yaitu 1) menjadi dasar belajar, 2) menjadi dasar pengembangan kemampuan bahasa tulis, 3) menunjang keterampilan berbahasa lannya, 4) memperlancar komunikasi lisan, dan 5) menambah informasi atau pengetahuan. Fungsi- fungsi ini membuat menyimak menjadi hal penting yang harus sedini mungkin diberikan pada anak. Selain itu dalam proses menyimak ada dua aspek tujuan yang perlu diperhatikan (Sutari dkk, 1972: 22), yaitu 1) adanya pemahaman dan umpan balik dari penyimak terhadap pesan yang disampaikan oleh pembicara dan 2) pemahaman dan umpan balik yang diberikan oleh penyimak terhadap pesan yang disampaikan.

Ragam menyimak yang dapat dikembangkan di Taman Kanak- Kanak menurut Bromley (dalam Dhieni, 2007: 4.11) adalah: 1) menyimak informatif, 2) menyimak kritis, dan menyimak 3) menyimak apresiatif.
Menyimak informatif adalah menyimak yang bertujuan untuk mengidentifikasi dan mengingat fakta- fakta, ide- ide, dan hubungan- hubungan. Contoh kegiatan yang dapat diberikan adalah membacakan satu paragraf dari suatu cerita kemudian diberikan pertanyaan sederhana dari apa yang telah dibacakan.

Menyimak kritis adalah adalah kegiatan mendengarkan yang tujuannya lebih dari sekedar mengidentifikasi fakta, ide, dan hubungan- hubungan, akan tetapi sampai pada menganalisis apa yang didengar dan membuat generalisasi. Contoh kegiatan yang dapat diberikan adalah membacakan cerita kepada anak kemudian diberikan pertanyaan tentang alasan terjadinya jalan cerita yang telah diberikan (misal: kenapa si A bisa jatuh, dll).

Menyimak apresiatif adalah kemampuan menikmati dan merasakan apa yang didengar. Contoh kegiatan yang dapat diberikan adalah membacakan cerita kepada anak kemudian anak diajak untuk membicarakan tentang perasaan, suasana hati, atau gambaran yang muncul dalam cerita.

Dari semua pemaparan di atas terlihat bahwa kegiatan menyimak tidak bisa terlepas dari perhatian untuk mendengarkan orang lain tentang suatu informasi tertentu. Akan tetapi yang sering terjadi adalah perhatian anak terhadap sesuatu tidak dapat berlangsung lama, sehingga bahan informasi dan yang memberi informasi harus bisa menarik perhatian anak, salah satunya adalah dengan metode bercerita. Hal ini dikarenakan menyimak penjelasan dan nasehat orang lain merupakan sesuatu yang tidak menyenangkan bagi anak TK. Sebaliknya menyimak cerita atau dongeng adalah aktivitas yang mengasyikkan. Oleh karena itu sangat bijak dan cerdas apabila pemberian pelajaran dan nasehat dilakukan melalui metode bercerita atau dongeng (Musfiroh, 2005:23)

Metode bercerita adalah salah satu metode yang sering digunakan dalam pendidikan di PAUD/ TK. Metode bercerita dianggap efektif untuk menjadi pengantar bagi guru dalam memberikan informasi secara menyenangkan kepada anak. Secara umum bercerita atau mendongeng adalah suatu bentuk sastra lisan dari mulut seorang pencerita kepada sekelompok pendengar 
Jurnal PG-PAUD Trunojoyo : Jurnal Pendidikan dan Pembelajaran Anak Usia Dini, Volume 5, Nomor 1, April 2018, hal 1 - 9

(Tressyalina, 2008: 84). Sedangkan dalam proses pembelajaran Moeslichatoen (2004: 157) berpendapat bahwa metode bercerita adalah suatu pemberian pengalaman belajar dengan membawakana cerita kepada anak secara lisan. Cerita yang dibawakan oleh guru harus sesuai dengan tujuan pendidikan bagi anak tapi harus tetap dikemas dengan menarik agar dapat mengundang perhatian anak.

Musfiroh (2005: 141) menjabarkan tentang beberapa teknik penyajian cerita yang dapat digunakan oleh seorang guru dalam bercerita, yaitu 1) bercerita dengan alat peraga dan 2) bercerita tanpa alat peraga. Bercerita dengan alat peraga adalah bentuk penyajian cerita dengan menggunakan berbagai alat bantu. Beberapa alat bantu yang dapat digunakan adalah buku, gambar, boneka, papan flanel, dan film bisu. Semua alat peraga membutuhkan keterampilan tersendiri yang memungkinkan penggunaan alat peraga berfungsi secara optimal. Sedangkan bercerita tanpa alat peraga adalah cerita langsung yang bisa dilakukan oleh guru tanpa bantuan alat apapun kecuali diri guru itu sendiri.

\section{METODE}

Penelitian ini menggunakan jenis Penelitian Tindakan Kelas (PTK). Menurut Arikunto (2008 : 7) Penelitian Tindakan Kelas merupakan suatu pencermatan terhadap kegiatan belajar berupa sebuah tindakan, yang sengaja dimunculkan dan terjadi dalam sebuah kelas secara bersama. Tindakan tersebut diberikan oleh guru atau dengan arahan dari guru yang dilakukan oleh anak.

Penelitian Tindakan Kelas bertujuan untuk mengembangkan cara dalam mengatasi permasalahan yang terjadi dalam suatu proses pembelajaran, ketrampilan-ketrampilan baru, atau cara pendekatan baru untuk memecahkan masalah dengan penerapan langsung. Penelitian tindakan kelas dilaksanakan dalam bentuk siklus berulang yang di dalamnya terdapat empat tahapan utama yaitu perencanaan, tindakan, pengamatan, dan refleksi.

Penelitian ini dilaksanakan di TK Siti Khodijah Pucuk Lamongan dengan subyek berjumlah sepuluh anak. Penelitian ini menggunakan instrumen penelitian berupa lembar observasi, lembar wawancara, dan dokumentasi dengan enam indikator pengamatan.

\section{HASIL DAN PEMBAHASAN Hasil}

Berdasarkan hasil penelitian diperoleh data sebagi berikut.

\section{Tabel 1}

Indikator Kemapuan Menyimak Pada Anak

\begin{tabular}{|c|l|c|c|c|c|}
\hline No & \multicolumn{1}{|c|}{ Indikator } & BB & MB & BSH & BSB \\
\hline 1 & $\begin{array}{l}\text { Anak mampu mengarahkan } \\
\text { pandangan kepada guru } \\
\text { selema beberapa menit }\end{array}$ & & & & \\
\hline 2 & $\begin{array}{l}\text { Anak mamapu menghargai } \\
\text { pembicaraan orang lain }\end{array}$ & & & & \\
\hline 3 & $\begin{array}{l}\text { Anak mampu menunjukkan } \\
\text { ekspresi wajah sesuai } \\
\text { intruksi guru }\end{array}$ & & & & \\
\hline 4 & $\begin{array}{l}\text { Anak mampu menyebutkan } \\
\text { tokoh dalam cerita }\end{array}$ & & & & \\
\hline 5 & $\begin{array}{l}\text { Anak mampu menunjuk } \\
\text { gambar sesuai intruksi guru }\end{array}$ & & & & \\
\hline 6 & $\begin{array}{l}\text { Anak mampu menyebutkan } \\
\text { sifat tokoh dalam cerita }\end{array}$ & & & & \\
\hline
\end{tabular}

Keterangan:

BB : Belum Berkembang (skor 1)

MB : Mulai Berkembang (skor 2)

BSH : Berkembang Sesuai Harapan (skor 3)

BSB : Berkembang Sangan Baik (skor 4)

Data yang diperoleh dari pengamatan terhadap indikator kemampuan menyimak pada anak selama penelitian kemudian dianalisis menggunakan patokan standar keberhasilan yang dikategorikan secara perorangan dan secara klasikal. Kategori perseorangan dikatakan berhasil apabila anak memenuhi ketuntasan belajar dengan kriteria Berkembang Sesuai Harapan (BSH) atau nilai minimal 3, sedangkan untuk keberhasilan klasikal dianggap terpenuhi jika persentase keberhasilan mencapai $80 \%$. Hal ini berarti bahwa anak yang mendapat skor 3 atau Berkembang Sesuai Harapan (BSH) harus mencapai $80 \%$ dari sepuluh anak.

Selanjutnya dalam menghitung persentase keberhasilan secara klasikal digunakan rumus sebagai berikut :

$$
P=\frac{\sum \text { Siswa yang tuntas belajar }}{\sum \text { Siswa }} \times 100 \%
$$

(Aqib, dkk, 2009: 205)

Penelitian ini diawali dengan pengamatan pada kegiatan prasiklus untuk melihat kemampuan awal yang dimiliki oleh anak berkaitan dengan kemampuan menyimak. Dari hasil pengamatan pada kegiatan prasiklus dapat diperoleh data kemampuan menyimak 
pada anak yang masih rendah. Adapun data kemampuan menyimak anak pada pengamatan awal atau prasiklus sebagai berikut:

\section{Tabel 2}

Kemampuan Menyimak Anak (Prasiklus)

\begin{tabular}{|c|c|c|c|c|c|c|c|c|c|}
\hline \multirow{2}{*}{ Nama } & \multicolumn{6}{|c|}{ Indikator } & \multirow{2}{*}{$\begin{array}{l}\text { Rata- } \\
\text { Rata }\end{array}$} & \multirow{2}{*}{$\begin{array}{c}\text { Pembulat } \\
\text { an }\end{array}$} & \multirow{2}{*}{ Ket } \\
\hline & 1 & 2 & 3 & 4 & 5 & 6 & & & \\
\hline AS & 2 & 2 & 1 & 1 & 1 & 2 & 1,50 & 2 & MB \\
\hline $\mathrm{AZ}$ & 1 & 1 & 2 & 2 & 1 & 2 & 1,50 & 2 & $\mathrm{MB}$ \\
\hline DR & 3 & 2 & 3 & 2 & 3 & 2 & 2,50 & 3 & $\mathrm{BSH}$ \\
\hline MA & 2 & 3 & 2 & 3 & 3 & 2 & 2,50 & 3 & BSH \\
\hline $\mathrm{MN}$ & 2 & 1 & 1 & 2 & 1 & 1 & 1,33 & 1 & $\mathrm{BB}$ \\
\hline MR & 1 & 2 & 1 & 1 & 2 & 2 & 1,50 & 2 & MB \\
\hline NR & 3 & 3 & 2 & 3 & 3 & 2 & 2,67 & 3 & BSH \\
\hline $\mathrm{RD}$ & 2 & 1 & 1 & 2 & 1 & 2 & 1,50 & 2 & $\mathrm{MB}$ \\
\hline RO & 1 & 1 & 2 & 2 & 1 & 1 & 1,33 & 1 & $\mathrm{BB}$ \\
\hline $\mathrm{SF}$ & 1 & 2 & 1 & 1 & 2 & 2 & 1,50 & 2 & $\mathrm{MB}$ \\
\hline SL & 3 & 3 & 3 & 2 & 2 & 2 & 2,50 & 3 & $\mathrm{BSH}$ \\
\hline $\mathrm{TT}$ & 2 & 1 & 1 & 2 & 1 & 2 & 1,50 & 2 & $\mathrm{MB}$ \\
\hline
\end{tabular}

Data tersebut menunjukkan bahwa anak yang telah mencapai kemampuan sesuai standar yang telah ditetapkan masih sangat rendah. Dari keseluruhan indikator yang telah diamati hanya terdapat empat anak yang mendapat skor 3 dengan kriteria Berkembang Sesuai Harapan (BSH). Adapun nilai persentase kemampuan menyimak anak sebagai berikut:

Tabel 3

Persentase Kemampuan Menyimak Anak (Prasiklus)

\begin{tabular}{|c|c|c|c|}
\hline Skor & $\begin{array}{c}\text { Jumlah } \\
\text { Anak }\end{array}$ & Persentase & Keterangan \\
\hline 1 & 2 & $16,67 \%$ & Belum Berkembang \\
\hline 2 & 6 & $50 \%$ & Mulai Berkembang \\
\hline 3 & 4 & $33,33 \%$ & $\begin{array}{c}\text { Berkembang Sesuai } \\
\text { Harapan }\end{array}$ \\
\hline 4 & 0 & $0 \%$ & $\begin{array}{c}\text { Berkembang Sangat } \\
\text { Baik }\end{array}$ \\
\hline Total & & $100 \%$ & \\
\hline
\end{tabular}

Data persentase kemampuan menyimak anak dengan enam indikator di atas menunjukkan bahwa dari dua belas anak yang diamati hanya terdapat empat anak yang mendapat kriteria Berkembang Sesuai Harapan (BSH) atau hanya 33,33\%. Hal ini kemudian dirasa perlu dilakukan tindakan untuk meningkatkan kemampuan menyimak pada anak melalui metode bercerita pada pertemuan selanjutnya atau pada siklus 1 .

\section{Siklus 1}

\section{Perencanaan}

Pada pertemuan di siklus 1 meliputi perencanaan, tindakan, pengamatan, dan refleksi. Pada siklus 1 kegiatan perencanaan berisi kesiapan guru dalam merencanakan pembelajaran untuk meningkatkan kemampuan menyimak pada anak melalui metode bercerita. Kegiatan ini berupa pembuatan $\mathrm{RPPH}$, penyiapan variasi media yang akan digunakan untuk bercerita, pemilihan cerita yang akan diberikan, dan penyiapan lembar pengamatan.

\section{Tindakan}

Tindakan pada siklus 1 dilaksanakan pada tanggal 8 Januari 2018. Pembelajaran berlangsung mulai pukul 07.30-09.00 dengan anak yang berjumlah dua belas. Media yang disiapkan yaitu buku cerita bergambar, sedangkan cerita yang dibacakan berjudul "Kerbau dan Buaya" Guru juga memberikan penguatan kepada anak ketika anak memberikan respon atas intruksi yang diberikan oleh guru baik itu respon yang sudah sesuai maupun tidak. Cerita yang dibacakan oleh guru adalah cerita sederhana dengan tiga tokoh cerita, hal ini dimaksudkan agar isi cerita dapat dengan mudah diterima oleh anak.

Metode bercerita ini dilakukan dengan cara guru menunjukkan gambar secara langsung kepada anak dengan variasa suara dan variasa nada dalam bercerita. Selain itu baik disela-sela maupun diakhir cerita guru akan memberikan pertanyaan-pertanyaan untuk menggali pemahaman anak dan juga untuk melihat kemampuan anak dalam menyimak suatu informasi dari sebuah cerita.

\section{Pengamatan}

Langkah selanjutnya yang dilakukan guru adalah melakukan pengamatan terhadap enam indikator yang sebelumnya telah ditetapkan untuk melihat kemampuan menyimak anak melalui metode bercerita. Dari hasil pengamatan ini diperoleh data tentang kemampuan menyimak anak sebagaimana berikut:

\section{Tabel 4}

Kemampuan Menyimak Anak (Siklus 1)

\begin{tabular}{|c|c|c|c|c|c|c|c|c|c|}
\hline \multirow{2}{*}{ Nama } & \multicolumn{7}{|c|}{$\begin{array}{c}\text { Rata- } \\
\text { Rata }\end{array}$} & $\begin{array}{c}\text { Pembulat } \\
\text { an }\end{array}$ & Ket \\
\hline & 1 & 2 & 3 & 4 & 5 & 6 & \\
\hline AS & 3 & 3 & 2 & 3 & 2 & 2 & 2,50 & 3 & BSH \\
\hline AZ & 2 & 2 & 3 & 2 & 2 & 2 & 2,17 & 2 & MB \\
\hline DR & 3 & 3 & 2 & 3 & 2 & 3 & 2,67 & 3 & BSH \\
\hline MA & 3 & 3 & 3 & 3 & 3 & 3 & 3,00 & 3 & BSH \\
\hline MN & 2 & 2 & 2 & 2 & 2 & 2 & 2,00 & 2 & MB \\
\hline MR & 2 & 3 & 2 & 2 & 3 & 3 & 2,50 & 3 & BSH \\
\hline NR & 3 & 3 & 3 & 3 & 3 & 3 & 3,00 & 3 & BSH \\
\hline RD & 3 & 2 & 2 & 2 & 2 & 2 & 2,17 & 2 & MB \\
\hline RO & 2 & 2 & 3 & 2 & 2 & 2 & 2,17 & 2 & MB \\
\hline
\end{tabular}


Jurnal PG-PAUD Trunojoyo : Jurnal Pendidikan dan Pembelajaran Anak Usia Dini, Volume 5, Nomor 1, April 2018, hal 1 - 9

\begin{tabular}{|l|l|l|l|l|l|l|l|l|l|}
\hline SF & 2 & 3 & 2 & 2 & 2 & 2 & 2,17 & 2 & MB \\
\hline SL & 3 & 3 & 3 & 3 & 3 & 3 & 3,00 & 3 & BSH \\
\hline TT & 3 & 2 & 2 & 2 & 2 & 2 & 2,17 & 2 & MB \\
\hline
\end{tabular}

Data tersebut menunjukkan bahwa telah terjadi peningkatan pada kemampuan menyimak pada anak melalui metode bercerita. Dilihat dari indikator keseluruhan dapat diketahui bahwa ada peningkatan jumlah anak yang mencapai skor 3 atau Berkembang Sesuai Harapan (BSH). Awalnya pada pengamatan prasiklus terdapat empat anak yang mencapai skor 3 untuk nilai rata- rata dari keseluruhan indikator yang kemudian menjadi enam anak. Sedangkan anak yang mendapat skor 1 atau Belum Berkembang (BB) sudah tidak ada lagi. Adapun nilai persentase kemampuan menyimak anak sebagai berikut:

\section{Tabel 5}

Persentase Kemampuan Menyimak Anak Menggunakan Metode Bercerita (Siklus 1)

\begin{tabular}{|c|c|c|c|}
\hline Skor & $\begin{array}{c}\text { Jumlah } \\
\text { Anak }\end{array}$ & Persentase & Keterangan \\
\hline 1 & 0 & $0 \%$ & Belum Berkembang \\
\hline 2 & 6 & $50 \%$ & Mulai Berkembang \\
\hline 3 & 6 & $50 \%$ & $\begin{array}{c}\text { Berkembang Sesuai } \\
\text { Harapan }\end{array}$ \\
\hline 4 & 0 & $0 \%$ & $\begin{array}{c}\text { Berkembang Sangat } \\
\text { Baik }\end{array}$ \\
\hline Total & \multicolumn{3}{|c|}{ Data persentase di atas menunjukkan }
\end{tabular}
bahwa anak yang mencapai skor 1 sudah menurun menjadi 0\% dari semula sebesar $16,67 \%$. Persentase anak yang mencapai skor 3 sudah mulai meningkat menjadi $50 \%$ dari semula yang hanya $33,33 \%$, namun hal ini belum mencapai standar keberhasilan penelitian yang harus mencapai $80 \%$.

\section{Refleksi}

Refleksi adalah kegiatan perenungan kembali untuk menyiapkan tindakan pada siklus selanjutnya. Hasil yang digambarkan pada tabel di siklus 1 menjelaskan bahwa dari dua belas orang anak terdapat 50\% atau 6 anak yang sudah Mulai Berkembang (MB), sedangkan untuk anak yang sudah Berkembang Sesuai Harapan (BSH) baru mencapai 50\% atau 6 anak dan belum ada anak yang mencapai kategori Berkembang Sangat Baik (BSB).

Mengacu pada kondisi tersebut, maka hasil penelitian dapat dikatakan masih rendah. Jumlah anak yang mencapai skor 3 juga belum mencapai standar keberhasilan yakni sebesar $80 \%$. Ketidakberhasilan proses peningkatan kemampuan menyimak melalui metode bercerita pada siklus 1 ini disebabkan karena beberapa kendala sebagai berikut :

1. Perhatian beberapa anak masih mudah teralihkan ketika guru membacakan cerita sehingga ada anak merasa kesulitan ketika diberikan pertanyaan berkaitan dengan cerita.

2. Beberapa anak terkadang mengganggu temannya yang sedang memperhatikan guru sehingga kondisi pembelajaran terkadang sedikit gaduh.

3. Beberapa anak suka menyela kegiatan bercerita yang sedang dilakukan oleh guru dengan cerita anak yang keluar dari tema cerita.

Kendala-kendala yang terjadi pada siklus 1 ini menjadi tolok ukur bagi guru untuk melakukan perbaikan pada siklus 2 dengan bidang pengembangan yang sama yakni meningkatkan kemampuan menyimak melalui metode bercerita pada anak kelompok A di TK Siti Khodijah Pucuk Lamongan.

\section{Siklus 2}

Pelaksanaan siklus 2 dimaksudkan untuk mengatasi kendala-kendala dan memperbaiki proses pembelajaran agar masalah yang terdapat pada siklus 1 dapat teratasi. Tindakan pada siklus 2 dilakukan pada tanggal 15 Januari 2018. Adapun pelaksanaannya dapat diuraikan sebagai berikut :

\section{Perencanaan}

Berdasarkan hasil refleksi pada siklus 1, kendala-kendala yang perlu diperbaiki dalam proses pembelajaran sebagai berikut :

1. Perhatian beberapa anak masih mudah teralihkan ketika guru membacakan cerita sehingga ada anak merasa kesulitan ketika diberikan pertanyaan berkaitan dengan cerita.

2. Beberapa anak terkadang mengganggu temannya yang sedang memperhatikan guru sehingga kondisi pembelajaran terkadang sedikit gaduh.

3. Beberapa anak suka menyela kegiatan bercerita yang sedang dilakukan oleh guru dengan cerita anak yang keluar dari tema cerita.

Hal-hal yang perlu dipertahankan pada proses pembelajaran siklus 1 yang dianggap sebagai kekuatan untuk siklus berikutnya yaitu :

1. Guru melaksanakan rencana tindakan sesuai dengan RPPH yang telah 
disusun berdasarkan hasil evaluasi sebelumnya.

2. Guru membawakan cerita sederhana dengan dibatasi tiga tokoh cerita dengan variasi suara dan variasi nada.

3. Guru selalu memberikan pertanyaanpertanyaan disela-sela penyajian cerita untuk menarik perhatian anak.

Adapun kegiatan perencanaan pada siklus 2 berupa pembuatan RPPH, penyiapan variasi media yang akan digunakan untuk bercerita, pemilihan cerita yang akan diberikan, dan penyiapan lembar pengamatan.

\section{Tindakan}

Tindakan pada siklus 2 dilaksanakan pada tanggal 15 Januari 2018. Pembelajaran berlangsung mulai pukul 07.30-09.00 dengan anak yang berjumlah dua belas. Media yang disiapkan yaitu buku cerita bergambar dengan ukuran lebih besar daripada buku cerita bergambar pada siklus 1. Cerita yang dibacakan berjudul "Tikus dan Singa" Dalam membawakan cerita guru lebih banyak melakukan improvisasi, sehingga pandangan guru tidak terpaku pada buku cerita. Guru juga berjalan-jalan menghampiri murid yang sedang duduk melingkar, sehingga anak benarbenar memperhatikan guru. Tidak lupa guru memberikan penguatan kepada anak ketika anak memberikan respon atas intruksi yang diberikan oleh guru baik itu respon yang sudah sesuai maupun tidak. Cerita yang dibacakan oleh guru adalah cerita sederhana dengan tiga tokoh cerita, hal ini dimaksudkan agar isi cerita dapat dengan mudah diterima oleh anak.

Metode bercerita ini dilakukan dengan cara guru menunjukkan gambar secara langsung kepada anak dengan variasa suara dan variasa nada dalam bercerita. Selain itu baik disela-sela maupun diakhir cerita guru akan memberikan pertanyaan-pertanyaan untuk menggali pemahaman anak dan juga untuk melihat kemampuan anak dalam menyimak suatu informasi dari sebuah cerita.

\section{Pengamatan}

Pengamatan dilakukan untuk melihat ketercapaian indikator kemampuan menyimak melalui metode bercerita yang telah ditetapkan. Adapun hasil pengamatan kemampuan menyimak anak pada siklus 2 sebagaimana berikut:
Tabel 6

Kemampuan Menyimak Anak (Siklus 2)

\begin{tabular}{|c|c|c|c|c|c|c|c|c|c|}
\hline Nama & & & ndi & ato & & & Rata- & Pembula & Ket \\
\hline & 1 & 2 & 3 & 4 & 5 & 6 & & & \\
\hline AS & 3 & 3 & 3 & 3 & 3 & 3 & 3,00 & 3 & $\mathrm{BSH}$ \\
\hline $\mathrm{AZ}$ & 3 & 3 & 3 & 3 & 3 & 3 & 3,00 & 3 & $\mathrm{BSH}$ \\
\hline DR & 4 & 3 & 3 & 3 & 3 & 3 & 3,17 & 3 & $\mathrm{BSH}$ \\
\hline MA & 4 & 3 & 3 & 3 & 4 & 4 & 3,50 & 4 & BSB \\
\hline $\mathrm{MN}$ & 2 & 3 & 2 & 3 & 2 & 2 & 2,33 & 2 & $\mathrm{MB}$ \\
\hline MR & 3 & 3 & 2 & 3 & 3 & 2 & 2,67 & 3 & $\mathrm{BSH}$ \\
\hline NR & 4 & 4 & 4 & 3 & 3 & 3 & 3,50 & 4 & BSB \\
\hline $\mathrm{RD}$ & 3 & 3 & 3 & 3 & 3 & 2 & 2,83 & 3 & $\mathrm{BSH}$ \\
\hline RO & 4 & 3 & 4 & 3 & 3 & 4 & 3,50 & 4 & BSB \\
\hline SF & 3 & 3 & 3 & 3 & 2 & 2 & 2,67 & 3 & $\mathrm{BSH}$ \\
\hline SL & 3 & 3 & 3 & 3 & 3 & 3 & 3,00 & 3 & $\mathrm{BSH}$ \\
\hline TT & 2 & 3 & 3 & 2 & 2 & 2 & 2,33 & 2 & $\mathrm{MB}$ \\
\hline
\end{tabular}

Data di atas memberikan gambaran bahwa telah terjadi peningkatan pada kemampuan menyimak pada anak melalui metode bercerita. Dilihat dari indikator keseluruhan dapat diketahui bahwa telah terjadi peningkatan jumlah anak yang mencapai skor 3. Awalnya pada pengamatan siklus 1 terdapat enam anak yang mencapai skor 3 untuk nilai rata- rata dari keseluruhan indikator yang kemudian menjadi tujuh anak dan tiga anak mencapai nilai rata-rata dengan skor 4. Adapun nilai persentase kemampuan menyimak anak sebagaimana berikut:

\section{Tabel 7}

Persentase Kemampuan Menyimak Anak Menggunakan Metode Bercerita (Siklus 2)

\begin{tabular}{|c|c|c|c|}
\hline Skor & $\begin{array}{c}\text { Jumlah } \\
\text { Anak }\end{array}$ & Persentase & Keterangan \\
\hline 1 & 0 & $0 \%$ & Belum Berkembang \\
\hline 2 & 2 & $16,67 \%$ & Mulai Berkembang \\
\hline 3 & 7 & $58,33 \%$ & $\begin{array}{c}\text { Berkembang Sesuai } \\
\text { Harapan }\end{array}$ \\
\hline 4 & 3 & $25 \%$ & $\begin{array}{c}\text { Berkembang Sangat } \\
\text { Baik }\end{array}$ \\
\hline Total & 12 & $100 \%$ & \\
\hline
\end{tabular}

\section{Refleksi}

Nilai keberhasilan pada siklus 2 secara keseluruhan telah mencapai persentase 83,33\% dengan rincian $58,33 \%$ untuk anak yang berhasil mendapat skor 3 dengan kriteria Berkembang Sesuai Harapan (BSH) dan 25\% untuk anak yang mendapat skor 4 dengan kriteria Berkembang Sangat Baik (BSB). Hasil dari pengamatan pada siklus 2 ini sekaligus menentukan bahwa Penelitian Tindakan Kelas dapat dilaksanakan hanya sampai siklus 2 , hal ini mengacu pada standar keberhasilan yang telah direncanakan yaitu kriteria keberhasilan 
Jurnal PG-PAUD Trunojoyo : Jurnal Pendidikan dan Pembelajaran Anak Usia Dini, Volume 5, Nomor 1,

perseorangan dianggap terpenuhi apabila anak memenuhi ketuntasan belajar dengan kriteria baik atau nilai minimal 3, sedangkan untuk keberhasilan klasikal patokan keberhasilannya harus mencapai $80 \%$, sehingga apabila hasil dari penelitian telah mencapai $80 \%$ maka penelitian dapat dihentikan, begitu pula sebaliknya.

Kendala-kendala yang menjadi hambatan selama penelitian pada siklus 1 seperti :

1. Perhatian beberapa anak masih mudah teralihkan ketika guru membacakan cerita sehingga ada anak merasa kesulitan ketika diberikan pertanyaan berkaitan dengan cerita.

2. Beberapa anak terkadang mengganggu temannya yang sedang memperhatikan guru sehingga kondisi pembelajaran terkadang sedikit gaduh.

3. Beberapa anak suka menyela kegiatan bercerita yang sedang dilakukan oleh guru dengan cerita anak yang keluar dari tema cerita.

Kendala-kendala ini bisa diatasi dengan guru menunjuk anak untuk menjawab pertanyaan dari guru. Hal ini bisa dijadikan solusi karena guru memberitahu kepada anak bahwa guru akan memberikan bintang bagi yang bisa menjawab pertanyaan dari guru, sehingga anak-anak lebih berkonsentrasi dan memperhatikan guru dengan benar. Selain itu guru selalu berusaha melakukan improvisasi terhadap cerita dan juga mendatangi anak dengan cara melakukan gerakan-gerakan yang ada di dalam cerita secara mengagetkan, terkadang guru juga melakukan cerita sambil berbisik yang membuat anak mendekat untuk menyimak cerita.

\section{Pembahasan}

Penelitian Tindakan Kelas tentang "Meningkatkan Kemampuan Menyimak Melalui Metode Bercerita Pada Anak Kelompok A Di TK Siti Khodijah Pucuk Lamongan" ini telah dilakukan secara bertahap, di mana perencanaan tindakan pada siklus 1 bersumber dari masalah-masalah yang menghambat kemampuan menyimak pada anak sehingga kemampuan awal dalam menyimak pada anak relatif rendah yang kemudian terjadi peningkatan pada setiap siklusnya. Peningkatan kemampuan menyimak yang dicapai oleh anak telah menunjukkan hasil yang signifikan, keadaan ini menjelaskan bahwa dalam proses pembelajaran harus bersifat dinamis dan peningkatan kemampuan menyimak pada anak sangat ditentukan oleh metode pembelajaran yang digunakan, seperti metode bercerita.

Pemilihan Metode dan langkah-langkah pengajaran yang dilakukan oleh guru merupakan hal yang menetukan dalam proses belajar mengajar, khususnya di lembaga Taman Kanak-Kanak. Metode dan langkahlangkah pengajaran yang digunakan di lembaga Taman Kanak-Kanak hendaknya lebih bervariasi mengingat anak-anak usia prasekolah adalah anak-anak yang mudah bosan. Pendapat ini seperti yang telah dikemukakan oleh Hartati (2007: 15) bahwa anak usia prasekolah memiliki daya konsentrasi yang pendek. Hal ini menuntut guru untuk selalu berfikir kreatif untuk membuat kegiatan-kegiatan baru dan bervariasi.

Perbaikan metode dan langkah-langkah tindakan dalam aktivitas belajar mengajar yang dilakukan oleh guru mempunyai pengaruh yang signifikan terhadap kemampuan anak. Perbaikan metode dan langkah-langkah dalam aktivitas belajar mengajar ini tampak dari kualitas pembelajaran dalam tindakan kelas yang telah dilakukan oleh guru untuk meningkatkan kemampuan menyimak anak pada setiap siklus sebagaimana tergambar dalam tabel berikut ini:

Tabel 8

Rekapitulasi Persentase Kemampuan Menyimak pada Anak

\begin{tabular}{|c|c|c|c|c|}
\hline Skor & Prasiklus & Siklus 1 & Siklus 2 & Ket. \\
\hline 1 & $16,67 \%$ & $0 \%$ & $0 \%$ & BB \\
\hline 2 & $50 \%$ & $50 \%$ & $16,67 \%$ & MB \\
\hline 3 & $33,33 \%$ & $50 \%$ & $58,33 \%$ & BSH \\
\hline 4 & $0 \%$ & $0 \%$ & $25 \%$ & BSB \\
\hline Total & $100 \%$ & $100 \%$ & $100 \%$ & \\
\hline
\end{tabular}

Keterangan:

BB : Belum Berkembang (skor 1)

MB : Mulai Berkembang (skor 2)

BSH : Berkembang Sesuai Harapan (skor 3)

BSB : Berkembang Sangan Baik (skor 4)

Rekapitulasi data persetanse ini menunjukkan kemampuan awal yang dimiliki anak dalam hal menyimak yang mencapai ketuntasan belajar hanya sebesar 33,33\%. Pada siklus 1 ketuntasan belajar yang dicapai oleh anak meningkat menjadi $50 \%$ dan pada siklus 2 meningkat lagi menjadi 83,33\%. Hasil akhir 
pada siklus 2 telah menuunjukkan peningkatan pada kemampuan menyimak anak melalui metode bercerita, sehingga anak yang masuk kriteria Belum Berkembang (BB) menjadi 0\% atau nihil, padahal awalnya persentase anak yang masuk kriteria ini mencapai $16,67 \%$ dan anak dengan kriteria Mulai Berkembang (MB) mencapai $50 \%$.

Hasil dari pengamatan terhadap kemampuan menyimak anak pada tiap siklus dapat menunjukkan bahwa metode bercerita dapat digunakan untuk meningkatkan kemampuan menyimak anak. Hal ini sesuai dengan pendapat Musfiroh (2005: 23) yang mengatakan bahwa menyimak penjelasan dan nasehat orang lain merupakan sesuatu yang tidak menyenangkan bagi anak TK. Sebaliknya menyimak cerita atau dongeng adalah aktivitas yang mengasyikkan. Oleh karena itu sangat bijak dan cerdas apabila pemberian pelajaran dan nasehat dilakukan melalui metode bercerita atau dongeng.

\section{Simpulan}

Berdasarkan hasil penelitian dan pembahasan yang telah dipaparkan maka dapat disimpulkan bahwa cara meningkatkan kemampuan menyimak melalui metode bercerita pada anak kelompok A di TK Siti Khodijah dilakukan melalui pemberian cerita secara langsung dengan media buku cerita bergambar. Kegiatan dilakukan dengan guru menerapkan cerita dengan variasi suara dan juga variasi nada dengan anak duduk dalam posisi melingkar. Kegiatan berakhir dengan anak menunjukkan beberapa respon sesuai intruksi guru yang berkaitan dengan cerita yang dibawakan oleh guru. Semua kegiatan menyimak melalui metode bercerita dilakukan dengan melibatkan seluruh anggota tubuh anak sehingga anak-anak menjadi senang dan mengalami peningkatan kemampuan dalam menyimak.

Peningkatan kemampuan menyimak pada anak terlihat dari data pada siklus 2 yang menunjukkan ketuntasan belajar mencapai persentase $83,33 \%$ dengan rincian 58,33\% untuk anak yang berhasil mendapat skor 3 dengan kriteria Berkembang Sesuai Harapan (BSH) dan 25\% untuk anak yang mendapat skor 4 dengan kriteria Berkembang Sangat Baik (BSB). Peningkatan ini mencapai 50\% mengingat pada pengamatan pra siklus hanya terdapat 33,33\% anak yang dikategorikan Berkembang Sesuai Harapan (BSH) dalam hal kemampuan menyimak.

\section{Saran}

Berdasarkan hasil simpulan di atas, maka dapat diberikan saran demi peningkatan kemampuan menyimak anak sebagai berikut:

1. Anak cenderung lebih tertarik ketika guru bercerita dengan media buku bergambar dengan ukuran yang lebih besar, sehingga hendaknya guru lebih sering menggunakan buku cerita bergambar dengan ukuran besar ketika melakukan pembelajaran dengan metode bercerita agar kemampuan menyimak anak semakin baik.

2. Pembelajaran dengan metode bercerita hendaknya dilengkapi dengan variasi suara dan variasi nada yang berbeda-beda.

3. Pembelajaran dengan metode bercerita juga bisa dilakukan dengan teknik cerita langsung dari anak agar anak belajar untuk mendengarkan temannya yang sedang bercerita

4. Kegiatan bercerita tetap selalu diberikan walaupun waktunya sempit, karena kegiatan ini dapat menanmkan pelajaranpelajaran untuk anak dengan cara menyenangkan.

\section{DAFTAR PUSTAKA}

Alwi, H., dkk. (2005). Kamus Besar Bahasa Indonesia. Jakarta: Balai Pustaka

Aqib, Z., dkk. (2009). Penelitian Tindakan Kelas. Bandung: Yrama Widya.

Arikunto, S. (2008). Prosedur Penelitian Suatu Pendekatan Praktek. Jakarta : PT Rineka Cipta.

Dhieni, N., dkk. (2007). Metode Pengembangan Bahasa. Jakarta: Universitas Terbuka.

Hartati, S. (2007). How To Be a Good Teacher and To Be a Good Mother. Jakarta: Enno Media.

Jamaris, M. (2005). Pengembangan Multiple Intelligences dan Aplikasinya Melalui Pembelajaran Terpadu di Taman Kanak-Kanak. Jurnal Pendidikan dan Kebudayaan No. 053, Tahun ke-11. Jakarta: Badan Penelitian dan Pengembangan Departemen Pendidikan Nasional.

Moeslichatoen, R. (2004). Metode Pengajaran di Taman Kanak-Kanak. Jakarta: PT Rineka Cipta.

Musfiroh, T. (2005). Bercerita untuk Anak Usia Dini Panduan bagi Guru Taman Kanak-Kanak. Jakarta: Departemen Pendidikan Nasional. 
Jurnal PG-PAUD Trunojoyo : Jurnal Pendidikan dan Pembelajaran Anak Usia Dini, Volume 5, Nomor 1, April 2018, hal 1 - 9

Santrock, J. W. (2010). Perkembangan Anak. Jakarta: Erlangga.

Sutari, I., dkk. (1997). Menyimak. Jakarta: Departemen Pendidikan dan Kebudayaan.

Tarigan, H. G. (1994). Menyimak Sebagai Suatu Keterampilan Berbahasa. Bandung: Angkasa.

Tressyalina. (2008). Respon Verbal dan Nonverbal Anak Usia Prasekolah terhadap Dongeng. Jurnal Pembelajaran. Vol. 30, No. 02. Padang: Universitas Negeri Padang Press.

Wibowo, H. (2007). Peningkatan Kemampuan Menyimak Melalui Pemberdayaan Sumber Belajar pada Pelajaran Bahasa Indonesia. Jurnal Teknologi Pendidikan, (Online), Vol. 9, No. 2 (http://jurnal.pdii.lipi.go.id, diakses 04 November 2017). 